\title{
Passing Strange and post-civil rights blackness ${ }^{1}$

\author{
GAYLE WALD
}

The American in Europe is everywhere confronted with the question of his identity. ${ }^{2}$

In her groundbreaking 2000 article 'Black like this: race, generation, and rock in the post-civil rights era', anthropologist Maureen Mahon describes the 'contemporary condition of double-consciousness' that shapes the experiences of African-Americans growing up in the decades after the black freedom struggle of the 1950s and 1960s. ${ }^{3}$ Focusing on members of the Black Rock Coalition (BRC), a group of musician-activists working to reclaim the blackness of rock-and-roll, Mahon finds that these predominantly middle-class young African-Americansmost born after 1960 - inherit a historically specific set of challenges regarding race and racial self-definition. Whereas earlier generations struggled against de jure segregation and second-class citizenship, this 'post-civil rights' generation, as Mahon and others dub it, inherits a world in which important legislative and juridical victories have already been achieved. As middle-class Americans, they have been the beneficiaries of civil rights victories in school desegregation, affirmative action and equal employment. On the other hand, this generation must negotiate new challenges that emerge from new expressions of racism and changes in racial discourse. As Mahon discovers through detailed interviews with BRC members, even economic privilege does not mitigate this younger generation's struggles against exclusion, discrimination and racial definition. It is simply that these struggles take place amid a new set of social and political challenges.

Post-civil rights double-consciousness is the thematic, aesthetic and political terrain of the critically acclaimed musical Passing Strange, which had its most visible run at the Belasco Theatre on Broadway in 2008, and appeared in 2009 as a film by the director Spike Lee. ${ }^{4}$ In Passing Strange - the title is simultaneously

\footnotetext{
1 Thanks to Monique Rooney for her incisive and insightful comments on an earlier draft of this essay. My gratitude to Scott Barash, who has seen multiple versions of Passing Strange, and to Stacy Wolf, for her encouragement and shared passion for the musical.

2 Baldwin, James 1955, 'A question of identity', Notes of a Native Son, Beacon Press, Boston, Mass.

3 Mahon, Maureen 2000, 'Black like this: race, generation, and rock in the post-civil rights era', American Ethnologist, vol. 27, no. 2 (May), pp. 283-311.

4 Lee's Passing Strange is a film of the musical, rather than a reworking of the musical for the cinema. This is not to say that Lee's film and the Broadway version of Passing Strange are the same text in different media;
} 
a riff on Othello, a meditation on the 'strangeness' of identity, a commentary on expatriate/étranger experience and a reference to racial passing - we find a lively and robust engagement with the contradictions of post-civil rights racial discourse, in which blackness is represented as multiple and shifting and in which identity is assumed to be performative rather than natural. Indeed, in taking blackness for granted as a complex and dynamic experience rather than a determinate state of belonging or being, Passing Strange is a passing narrative for the post-passing era: hip to anti-essentialist critiques of race as a social construct, tuned in to the ways that blackness is lived through class, gender, embodiment, sexuality and geography, and self-conscious about the histories of black American cosmopolitanism and the contemporary social and political minefields delineated in phrases such as 'acting black' or 'acting white'.

Like other passing narratives in the twentieth-century American canonincluding James Weldon Johnson's Autobiography of an Ex-Colored Man, Jessie Fauset's Plum Bun and Nella Larsen's Quicksand-Passing Strange sends its protagonist across national borders, to Northern Europe, where he experiences a welcome reprieve from US racial definition. ${ }^{6}$ As a post-civil rights passing narrative, however, Passing Strange is also acutely aware of the mutableness of black experience in the diaspora and of the ways that black Americanness, in particular, circulates as a fetishised and desired cultural commodity for white Europeans. This is, in other words, a tale of black bohemian cosmopolitanism in which the middle-class black protagonist is already schooled in the twentiethcentury history of black bohemian cosmopolitanism. And while the ending of Passing Strange returns the protagonist home - to mother love and to 'mother' country - the musical is reluctant to find resolution in the protagonist's embrace

rather, the forms of these representations render them radically different. Spectators of the Broadway version of Passing Strange witnessed a very particular kind of 'Broadway-sized' spectacle in the Belasco Theatre. Lee's excellent cinematic adaptation uses multiple cameras, film and video technologies and superb editing to create a more intimate text, with access to a point of view otherwise unavailable to theatre audiences (for example, extreme close-ups of actors' faces). By the same token, theatre spectators are privy to a more 'holistic' Passing Strange, in which the gaze can rest momentarily on different aspects of the spectacle (for example, a set of actors, a particular piece of scenery), but in which no camera mediates this gaze. In the Broadway version, the enormity of the wall of lights that acts as stage scenery is quite palpable; in Lee's film version, the feeling of this enormity is sacrificed for the spectator's ability - via the presence of cameras - to be 'onstage' with the performers. See Lee, Spike (dir) 2008, Passing Strange, US Narrative Feature Films, 135 minutes.

5 For more on the notion of 'post-passing' narratives - that is, narratives about passing produced in a historical era in which the economic and social incentives to pass have lessened - see Wald, Gayle 2000, Crossing the Line: Racial passing in US literature and culture, Duke University Press, Durham, NC. For an example of a recent, excellent essay that considers passing narratives beyond the black/white paradigm, see Harrison-Kahan, Lori 2005, 'Passing for white, passing for Jewish: mixed race identity in Danzy Senna and Rebecca Walker', MELUS, vol. 30, no. 1 (Spring), pp. 19-48. On ideas of 'acting black' or 'acting white', particularly as they relate to African-American schoolchildren, see Fordam, Signithia 1996, Blacked Out: Dilemmas of race, identity, and success at Capital High, University of Chicago Press.

6 These novels appeared during the 'cosmopolitan' moment of the New Negro Renaissance. See Weldon Johnson, James 1912 [1927], Autobiography of an Ex-Colored Man, Vintage, New York; Redmon Fauset, Jessie 1929, Plum Bun: A novel without a moral, Beacon Press, Boston, Mass.; Larsen, Nella 1928, Quicksandand Passing, Rutgers University Press, New Brunswick, NJ. 
of what Michelle Stephens, in her article 'What is this black in black diaspora?', calls 'color' or 'race' consciousness. ${ }^{7}$ Indeed, the successes and struggles of generations of African-Americans who laboured under conditions of segregation, poverty and second-class citizenship have afforded the protagonist both geographical mobility and the freedom to experiment with identity, but the multiplication of his choices is, in the end, an object of continuing negotiation. At worst, the musical suggests, the freedom to experiment with identity in the contemporary era can turn to an exercise in narcissism and self-delusion; at best, however, it can be a rich source of creative and artistic energy.

What I am calling Passing Strange's engagement with the contradictions of postcivil rights racial discourse is made manifest in its dual focus on 'the Youth', a middle-class black male teenager who cannot seem to 'correctly' appreciate the comforts afforded by his nationality and class, and 'the Narrator', the Youth's present-day alter ego, who invites us to join him in recalling his greener days. For the Youth, an aspiring musician growing up in the palm tree-studded 'colored paradise' of South Central Los Angeles circa 1980, what his peers, church and family deem ideal seems shallow and 'phoney' ${ }^{8}$ Despite the echo of The Catcher in the Rye, here, we are not exactly in the territory of Holden Caulfield; for the Youth, 'phoniness' is the distinct quality of his black bourgeois community, where the peak of educational attainment is a 'B.A. in communications from a prestigious black college' and Sunday-morning church has been reduced to a 'Baptist fashion show'. ${ }^{9}$ As the Youth sees it, this is the phoniness of black people who have 'made it' in Reagan-era America and who are more concerned with outward shows of 'American' success than with inward quests for meaning. Racism persists; indeed, Passing Strange abounds with references to the ways the Youth is profiled and feared, stereotyped and pigeonholed. Yet racism, per se, is not the Youth's or the musical's primary concern. Rather, it is the struggle to discover an authentic way of being - and of being an artist in particularthat drives the character and the narrative. For the Youth, this struggle entails the rejection of his community's seeming parochialism and the embrace of a multiracial, multinational, pan-sexual bohemianism, in which he is able to pursue different modalities of 'blackness'. In the course of the musical, he comes to reexamine this initial and youthful rejection of what he once saw as impediments

7 Stephens, Michelle 2009, 'What is this black in black diaspora?', Small Axe: A Caribbean journal of criticism, vol. 13, no. 2, p. 27. For Stephens, 'color consciousness suggests an epidermal, physiognomic, and visual understanding of race', whereas 'race consciousness implies both an understanding of the shared conditions and cultural bonds that might unite a racial group... and the collective impact of their combined struggles against oppression and for freedom' (p. 27). Stephens' title is an allusion to Stuart Hall's 1993 essay 'What is this black in black popular culture?'. I thank Constance Woodard Green, a PhD student in English at George Washington University, for bringing this article to my attention.

8 Stew 2009, Passing Strange: The complete book and lyrics of the Broadway musical, Book and Lyrics by Stew, Music by Stew and Heidi Rodewald, Created in collaboration with Annie Dorsen, Applause, New York. Subsequent citations will be from this text.

9 Ibid., pp. 19, 4. 
to his discovery of authenticity. To get to a place where he can reconcile the desire for alternatives and his appreciation for 'home', however, he pursues a path of downward mobility, away from his community's stale dreams of college and professional achievement and instead towards something simultaneously more elusive and, in the end, more liberating.

\section{Defining the 'post', defining passing}

Passing Strange's concern with depicting a specifically middle-class black postcivil rights experience dovetails with the biography of Stew, the multi-talented African-American musician who wrote and composed Passing Strange along with his long-time musical collaborator Heidi Rodewald, a white singer-bassist. ${ }^{10}$ Like the Youth of Passing Strange, Stew (born Mark Stewart in 1961) grew up around Los Angeles, was influenced by the Los Angeles punk-rock scene that flourished in the late 1970s and early 1980s and spent time in Berlin pursuing avant-garde music and performance. ${ }^{11}$ Although Stew was not formally affiliated with the BRC when he and Rodewald formed their rock band, The Negro Problem, in 1995, according to Mahon, he had an 'integrated school experience and an early and perceived-as-problematic engagement with rock' ${ }^{12}$

In pointing out these similarities, I do not mean to conflate Stew's biography with those of the BRC members Mahon studies; rather, I am interested in marshalling ideas about post-civil rights society and culture as a means of understanding the genesis, meaning and reception of Passing Strange. ${ }^{13}$ The discourse of this 'generation' is of course heuristic; as Tera Hunter and Eric

10 This essay is, admittedly, complicit with a wider marginalisation of Rodewald as a creator of and performer in Passing Strange. Partly, the autobiographical elements of the musical seemingly demand a focus on Stewthe Youth-the Narrator as aligned characters or personae. I also have found, however, that in publicity for the musical and the Spike Lee film, Stew has dominated discussion and the visual imagery connected with Passing Strange. Rodewald has nowhere near his web presence, for example, and does not appear to have her own web page separate from her various musical collaborations. The ascription of authorship of Passing Strange to Stew alone might reasonably follow from the web site $<$ www.stewsongs.com $>$, which is described simultaneously as 'The Official STEW site' and 'Also the official site for Heidi Rodewald and The Negro Problem'.

11 I call The Negro Problem a 'rock' band, although of course even this label is restricting, given the range of musical styles, modes and genres Stew and Rodewald pursue. Sean Westergaard's biography of the band at AllMusic.com is helpful (<http://allmusic.com/cg/amg.dll?p=amg\&sql=11:gnfuxqqhld6e $\sim \mathrm{Tl}>$ ).

12 From personal correspondence with Maureen Mahon, 3 February 2010. For documentation of demographic changes among African-Americans since the 1950s and 1960s and the rise of the black middle class, see, for example: Landry, Bart 1987, The New Black Middle Class, University of California Press, Berkeley; Pattillo-McCoy, Mary 1999, Black Picket Fences: Privilege and peril among the black middle class, University of Chicago Press .

13 In addition to Mahon's article, works that have influenced my thinking on post-civil rights - or, as it is sometimes called, post-soul-include: Kitwana, Bakari 2002, The Hip Hop Generation: Young blacks and the crisis in African American culture, Basic Civitas, New York; Brooks, Daphne 2004, 'Burnt sugar: post-soul satire and rock memory', in Eric Weisbard (ed.), This is Pop: In search of the elusive at Experience Music Project, Harvard University Press, Cambridge, Mass.; Ellis, Trey 1989, 'The new black aesthetic', Callaloo, vol. 12, no. 1 (Winter), pp. 233-43; Jones, Lisa 1997, Bulletproof Diva, Anchor, New York; Mahon, Maureen 2004, Right 
Lott argue in trenchant responses to Trey Ellis's groundbreaking 1989 essay 'The new black aesthetic', the persistence of class, gender and geographical distinctions among African-Americans nullifies any notion of a monolithic postcivil rights 'generational' experience. ${ }^{14}$ That said, the notion of the 'post' does provide a useful starting point for an analysis of cultural texts such as Passing Strange, which represents African-American experience in the wake of 1960s and 1970s-era liberation struggles (including civil rights, black power, feminism and gay liberation) and amid a continuing, ever-changing backlash or pushback against the achievements of these struggles. Since the 1978 Bakke decision (in which the US Supreme Court ruled against the use of racial 'quotas' in college admissions), for example, the United States has witnessed de-industrialisation, the growth and suburbanisation of the black middle-class, demands for visibility and political power brought by black queer subjects, the decline of public support for affirmative action, rising rates of incarceration of black men and women (and the subsequent disenfranchisement of black felons), devastating urban epidemics of crack cocaine use, increasing numbers of Americans choosing to define themselves as biracial or multiracial and the rise of hip-hop from a local expression of New York City youth to a globally dominant form of youth cultural expression. Defining events in the era of the 'post' encompass everything from the crossover success of the Sugarhill Gang's Rapper's Delight (1977) to the emergence of the HIV/AIDS epidemic (early 1980s); from Jesse Jackson's presidential candidacy and the rise of the Rainbow Coalition (1984) to the confirmation hearing of US Supreme Court Justice Clarence Thomas (1991); from the Los Angeles riots (1992) to the Million Man March (1995); from the 2001 US invasion of Iraq to the devastation - wrought disproportionately on the black and the poor - in the aftermath of Hurricane Katrina (2005). In the light of this complex history, the election of America's first black president in 2008 is but one, albeit a significant, milestone - another boundary marker between 'then' and 'now'.

Although post-civil rights theorists and critics approach the question of the 'post' differently-disagreeing in particular about the significance of class divisions among African-Americans - all engage in one way or another with a significant contradiction in US racial discourse since the 1970s. This postcivil rights contradiction can be summarised as follows: whereas racism and racialisation (that is, the manner in which subjects are socially defined as 'black') persist in the post-civil rights era, they do so alongside a widely

to Rock: The Black Rock Coalition and the cultural politics of race, Duke University Press, Durham, NC; Neal, Mark Anthony 2002, Soul Babies: Black popular culture and the post-soul aesthetic, Routledge, New York; Tate, Greg 1992, Flyboy in the Buttermilk: Essays on contemporary America, Simon \& Schuster, New York.

14 For a more extensive critique of 'generational difference as a construct', see: Lott, Eric 1989, 'Response to Trey Ellis's: “The new black aesthetic"”, Callaloo, vol. 12, no. 1 (Winter), pp. 244-6; Hunter, Tera 1989, “'It's a man's man's man's world": specters of the old re-newed in Afro-American culture and criticism', Callaloo, vol. 12, no. 1 (Winter), pp. 247-9. 
shared perception - perhaps even a growing national consensus - that race no longer matters, especially for those 'post-soul babies', as Mark Anthony Neal dubs them, who grow up in more racially integrated social milieux. ${ }^{15}$ Whereas Mahon et al. go to great pains to explore young African-Americans' complex engagements - at the level of identity and identification - with continuing racial discrimination and marginalisation, what I am calling the 'post-civil rights racial contradiction' sweeps aside these complexities under the liberal sign of 'color blindness' or, more perniciously, under the reactionary sign of 'reverse discrimination', ironically paving the way for new modes of racial marginalisation. ${ }^{16}$

The election of Barack Obama has, if anything, only brought this post-civil rights contradiction to a boiling point, in the meantime making it more obvious as a contradiction. Although it was patently absurd at the time, in retrospect, the intense media coverage of the 'precise' racial identity of Obamathe-candidate circa 2007 and 2008 now appears to have been misguided and arguably racist. Similarly, the time and energy spent in heated media debates about whether African-Americans would see Obama as one of 'them' - even, it was simultaneously suggested (often without much evidence), that whites, Latinos and Asian Americans would be reluctant to cast their votes for a 'black' person-appear as little more than a deflection of consideration of the future of progressive politics in the twenty-first century. In short, these contradictory speculations that swirled about concerning Obama's 'race' and whether it 'made a difference' - indeed, the very presumption on the part of many US news media that such speculations were valid and newsworthy-emblematise a variety of post-civil rights anxieties about race. In particular, they point to a broad confusion about the significance of race in American life, where 'black' racial identities are subject to continuing and intense policing (discursive and 'real'), even as their social existence and significance are publicly questioned. ${ }^{17}$ Clearly - and as Obama has himself said - we need to be wary of declaring ours a 'post-race' society.

15 See Neal, Soul Babies. Neal's use of 'soul' and 'post-soul' as markers springs from his particular concern with black musical expression and with 'soul' as a wide-ranging umbrella term for various modes of black musical creativity in the 1960s, 1970s and beyond.

16 On these issues, see: Omi, Michael and Winant, Howard 1994, Racial Formation in the United States: From the 1960s to the 1990s, Second edition, Routlege, New York; Crenshaw, Kimberlé 1995, 'Race, reform, and retrenchment: transformation and legitimation in antidiscrimination law', in Kimberlé Crenshaw, Neil Gotanda, Gary Petter and Kendall Thomas (eds), Critical Race Theory: The key writings that formed the movement, New Press, New York, pp. 103-22.

17 Two significant assumptions buttress this question. The first is that African-American class privilege is now normative, or at least normative enough that the experiences of the middle class can substitute for the experiences of the group as a whole. The second, equally insidious assumption is that middle-class experience is racially transcendent. According to this assumption, the life experiences of middle-class black and white Americans are essentially identical, if only because both groups would seem to have access to the same institutions that confer cultural, economic and political power. 
That does not mean, however, that these new contradictions are not meaningful within discussions of race, colour blindness and racial passing. Just the opposite: new notions of racial passing find their way into contemporary discourse of race through these contradictions. Where Obama-the-presidential-candidate was concerned, these references to racial passing were occasionally quite explicit and were often invoked when conservative commentators voiced resentment at the supposed advantages enjoyed by racial or ethnic 'minorities' in a post-civil rights society. 'It's just a question, but in the "color-blind" America of today, is Barack Hussein Obama, Jr. passing for black? Is he using his father's side of the family to advance his presidential candidacy and denying his white American middle class heritage? Is he denying his Islamic heritage?' asked the blogger Conservative Beach Girl in an April 2007 post. ${ }^{18}$ Several aspects of this blog post are noteworthy: its ersatz ingenuousness ('It's just a question...'), its pointed use of Obama's middle name and the suffix ' $\mathrm{Jr}^{\prime}$, its casting of the spectre of 'Islamic heritage' as inherently suspect and its notion that in 'the "color-blind" America of today' Obama enjoys privilege for having a black Kenyan father, even as this father is the source of anxiety about race, nationality and religion.

Most germane for my purposes here is the blogger's use of the phrase 'passing for black' in her rhetorical question about Obama, a man of presumably 'mixed' background who uses his 'father's side of the family' to 'advance' his chances for the presidency. This blog post is only one instance, of course, but it illustrates what I will call a post-civil rights turn in the discourse of racial passing, one whose condition of possibility is the notion that black or even 'mixed-race' people can and will deploy 'blackness' as a mode of social and economic advantage. To understand the meaning of the blogger's use of the phrase 'passing for black', then, is to understand struggles over racial identity staged in the context of post-civil rights developments, including the backlash against the late twentieth-century US struggle for civil rights.

Of course, in using the phrase 'passing for black' in association with Obama, the blogger implicitly calls on the history and cultural memory of African-Americans 'passing for white'. While passing, as a social practice, had a long history, in the last decades of the twentieth century, scholars began looking closely at the rich cultural repository of passing narratives, exemplified in literary texts such as Charles Chesnutt's serialised novel The House Behind the Cedars (1900), Nella Larsen's novella Passing (1929) and George Schuyler's modernist satire Black No More (1931). In my own 2000 study, Crossing the Line: Racial passing in twentiethcentury US literature and culture, for example, I argued that for racially defined subjects, passing (usually but not always 'for white') was a complex mode of racial re-signification and appropriation whose condition of possibility was in

18 Viewed 20 May 2009, <http://politicalbeachgirl.blogspot.com/2007/04/barack-hussein-obama-passingfor-black.html>. The post is dated 22 April 2007. 
the 'one-drop rule' that prevailed in the United States well into the twentieth century. In a somewhat different vein, cultural theorist Amy Robinson examined the performativity of passing, wherein 'passing for white' was best understood not as an ontological claim on the part of racially defined subjects but as social theatre most successfully performed when its audience did not realise, let alone acknowledge, its theatricality. And in works such as Our America: Nativism, modernism, and pluralism, as well as his influential essay 'Autobiography of an ex-white man', the literary scholar Walter Benn Michaels cunningly used literary passing narratives, including James Weldon Johnson's fictional 1912 autobiography, to explore and critique theories of 'social constructionism', which had gained currency in the US academy since the publication of Henry Louis Gates junior's influential anthology 'Race', Writing, and Difference. ${ }^{19}$

Although they arrived at disparate conclusions and used disparate methodologies, these studies all began with the premise that race was a 'fiction of identity' (to recall the title of Elaine K. Ginsberg's seminal 1996 collection of essays) and that racial passing was an exceptionally useful site for theorising about the social production and deployment of racial difference. ${ }^{20}$ Narratives of racial passing revealed complex dynamics of pleasure and desire, shame and selfdoubt, ambition and longing - all of which cohered around the discourses of racial definition. More recent representations of 'passing for black' are similarly useful for theorising about race in the context of post-civil rights developments. For example, even in Conservative Blogger Girl's blog post about Obama, in which racial difference is essentialised and somaticised (as something produced by 'heritage'), it is also imagined as flexible, usable and unmoored from biology or the visual 'evidence' of the body.

Yet while both might depend on certain contradictions in US racial discourse, 'passing for black' - particularly as it has been evoked in post-civil rights contexts - is not the equivalent (or the reversal-that is, the equivalent in negative terms) of 'passing for white'. To equate the two, to suggest that they are simply interchangeable, is to confuse the utopian discourse of colour blindness with current social conditions, in which racial identities continue to matter,

19 Wald, Crossing the Line; Robinson, Amy 1994, 'It takes one to know one: passing and communities of common interest', Critical Inquiry, vol. 20 (Summer), pp. 715-36; Benn Michaels, Walter 1995, Our America: Nativism, modernism, and pluralism, Duke University Press, Durham, NC; Benn Michaels, Walter 1998, 'Autobiography of an ex-colored man: why race is not a social construction', Transition, vol. 73, pp. 122-43; Gates, Henry Louis jr (ed.) 1985, 'Race', Writing, and Difference, University of Chicago Press. In my own experience, Gates' edited volume (originally published as a special issue of the journal Critical Inquiry) was absolutely seminal in setting a new standard for critical theorising about race in the light of influential poststructuralist paradigms.

20 Ginsberg, Elaine K. (ed.) 1996, Passing and the Fictions of Identity, Duke University Press, Durham, NC. Benn Michaels, in particular, used cultural representations of passing to insist on what he saw as the fallacy of the social-constructionist argument-namely, its re-inscription of race in the face of its demonstrated status as a fiction. 'Either race is an essence, or there is no such thing as race,' he wrote in 'Autobiography of an exwhite man', p. 125. 
albeit not in isolation from other social markers. It is also to overlook how the discourse of 'blackness' has subtly shifted in the post-civil rights era and how black subjects (particularly middle-class subjects) deploy 'passing for black' as a means of negotiating continuing racialisation, including racialisation that ostensibly reverses the racist logic of the one-drop rule to code black identity as socially or culturally desirable. What I am suggesting here is that passing is deeply embedded in the social and historical conditions that also enable it.

\section{Passing Strange: in search of the real}

How do we untangle this confusion around post-civil rights racial identities? How does 'passing for black' emerge as a trope of post-civil rights racial discourse? In the rest of this essay, I turn to Passing Strange for some answers, finding them primarily in the musical's clever exploration of the idea of the Real'. ${ }^{21}$ The Real is many things in Passing Strange and its elusiveness as a concept (to define it is not unlike trying to define truth or beauty) is part of the point of the musical. Whatever the Real might be, however, the play-text is clear that for the Youth, it is not to be found in black middle-class success stories - at one point dismissively referred to as 'black folks passing for black' ${ }^{22}$ It is also not to be found in the United States, with its stultifying social rituals around race and policing of racialised bodies. Indeed, following in the footsteps of James Baldwin - only the most obvious influence - the Youth seeks to realise the Real outside the confining spaces of US racial logic. Whereas Baldwin sought to find an alternative to racial segregation and discrimination, the Youth - who lives in a post-civil rights society that has apparently legislated such nuisances away-ironically wants to leave America for similar reasons. The Youth might enjoy middle-class privilege, yet in Los Angeles he is nevertheless a target of fear, suspicion and racial profiling. The expressions of racial oppression might have changed since Baldwin's day, but 'race' remains a hurdle and a challenge to be worked out at the level of identity and identification.

\footnotetext{
21 Passing Strange opened in Broadway's Belasco Theatre on 28 February 2008 and closed in late July. Directed by and created in collaboration with Annie Dorsen, the show was nominated for seven Tony Awards (which honour work staged in Broadway theatres), including Best Musical. In addition to winning (for Stew) the Tony Award for Best Book, Passing Strange won the Drama Desk Award and the New York Drama Critics' Circle Award for Best Musical. In its incarnation as an off-Broadway show at New York's Public Theater, it won the 2008 Obie Award for Best New American Theater Piece. Previous to its run on Broadway, Passing Strange was an award-winning show at Berkeley Rep in California (where it opened in October 2006) and the Public Theater, an Off-Broadway venue in New York (where it opened in May 2007). I saw the show in the middle of its Broadway run, in April 2008. Although it is no longer a Broadway musical, Passing Strange exists in other media: in musical form as Passing Strange, the Original Broadway Cast Recording (2008); in literary form as Passing Strange: The complete book and lyrics of the Broadway musical (2009); and in cinematic form as a documentary, Passing Strange, directed by Spike Lee. The last premiered at the 2009 Sundance Film Festival. 22 Stew, Passing Strange, p. 25.
} 
If there is an impulse to 'pass' in Passing Strange then it is initially an impulse to be unburdened of social expectations and restrictions associated with the Youth's class, gender and race. As the Youth travels, however, ostensibly leaving his 'American' self, his family and his past behind him, he discovers, not unsurprisingly, that forms of social expectation continue to adhere to him and that they do so under the sign of his status as a 'black American', especially a black American from 'the street'. (The white Europeans are so shaped by the discourses of authenticity in black popular culture of the 1980s that they fail to imagine that the Youth does not come from 'the hood'.) Because he knows the history of African-American artist-expatriates of earlier generations - that Paris and London have already been 'done' by such illustrious writers as Baldwin, Richard Wright and Chester Himes, for example - the Youth sets himself a slightly different course, travelling first to socially permissive Amsterdam, where sex and hashish are readily available, and later to culturally riotous Berlin, then in the throes of pre-post-communist revolutionary fervour. Yet neither of these European locations offers a reprieve from racial definition. Indeed, the end of the musical finds the Youth back in Los Angeles, mourning his mother, who died while he was in Berlin, and yet strengthened by the realisation - enabled and transformed by his grief - that the Real, like race and categories of identity, is a 'construct', an elusive and ever-moving target. ${ }^{23}$

In updating twentieth-century narratives of African-American expatriation and racial passing, Passing Strange advances a complex representation of the operations of blackness outside the geographical borders of the United States. In Europe, the Youth immediately encounters the global incorporation of AfricanAmerican cultural expression as a purchasable commodity. By the time he arrives in Amsterdam and Berlin, that is, the black American protest cultures and identities of the 1960s - particularly those associated with black powerhave been fully appropriated by European youth culture. At the same time, the social relationship of white European youth to black youth-including, presumably, Europeans of African descent-remains relatively untransformed.

Such commodification of blackness at the level of culture is not, per se, newcertainly, Josephine Baker in 1920s Paris and Jimi Hendrix in 1960s London were, at different moments, consumed as black exotics - and yet the Society of the Spectacle has only intensified global fantasies of blackness, particularly the fantasy of a blackness opposed to capitalism and nationalism. ${ }^{24}$ For the Youth, who has grown up in a community that embraced, rather than rejected, the American Dream, the Europe of the late twentieth century is thus at times

\footnotetext{
23 Ibid., p. 101.

24 I would like to also say imperialism, but the participation of African-Americans in the twenty-firstcentury US-led wars in Iraq and Afghanistan, and the presence of Obama as Commander-in-Chief, perhaps undermines the image of the black American as a non-participant in the US imperialist/expansionist/ interventionist project. This is a matter of speculation, however, and outside the purview of this essay.
} 
highly confounding, a place that forces him to reconcile with his personal history - embodied and voiced in the play through the character of his mother. By mining such rich veins of social and cultural contradiction, Passing Strange refuses to romanticise expatriation as 'escape' - from race, from identity, from history - instead concluding, with Baldwin, that leaving America entangles the black American expatriate in a continuing confrontation with 'the question of identity'.

Hence, while the musical shows the Youth enjoying various freedoms in Europe - much of the pleasure of spectators comes from witnessing and identifying with the youth's happiness abroad-Passing Strange also goes to great pains to demonstrate how the Youth is bound by post-civil rights challenges, especially around blackness and black racial identity. His story is a variation on the familiar passing narrative, if only because among European comrades he finds his 'blackness' - specifically, his African-Americanness - to be an object of appreciation and desire rather than revulsion. He confronts the usual array of racial stereotypes, but he also enjoys transgressively revelling in the (white) Europeans' misconceptions of African-American masculinity. At his lowest point, he 'caters to Europeans' worst stereotypes of black Americans as he creates a style he calls "Afro-Industrial-Post-Minstrelismus"." ${ }^{25}$ If he passes for black, it is not because he is free of racial definition (that is, according to the social-constructionist logic), but because he is racially defined in a context in which the discourses of colour blindness and racial romanticisation coexist and mutually inform one another. This is a story that asks audiences to invest in the Youth's dreams of 'freedom', even as it proffers an inevitably more 'real' critique of the Narrator's youthful naivety.

A number of formal innovations enable Passing Strange to approach the Youth's search for the Real with critical self-consciousness and differentiate Passing Strange from other recent deservedly acclaimed Broadway musicals, such as Tony Kushner's semi-autobiographical Caroline, Or Change, which centres on a Jewish boy's burgeoning self-consciousness about race, class and gender in relation to his African-American maid, and which had a run at the Eugene $\mathrm{O}^{\prime}$ Neill Theatre in 2004. Most importantly, whereas the story of the Youth is set in the 1980s, the narration of this story (the play-narrative itself) takes place in the present,

25 Grode, Eric 2007, 'A long, strange trip', [Review of Passing Strange], New York Sun, 15 May 2007. A note here about reviews of the play: although the majority are warm in their praise for Stew and his collaborators, they also repeatedly misread the musical in telling ways. For example, in my survey of the published reviews, it was common for the reviewer to conflate Stew, who acted the part of the Narrator, with the Youth, who played the Narrator's younger self. Although the musical is clearly autobiographical, this equation of StewYouth is problematic in minimising the imaginative labours of the musical. As well, not a few reviews read the play's ending quite differently than I do here, interpreting the Youth's return home (to California) at the end of the play as confirmation, along with Dorothy, that 'there's no place like home'. What such reviews fail to take into account is how the Youth's travels, like Dorothy's travels, have been transformative, such that 'home' - however much it is embraced - can never look or be the same again. 
giving the musical a sort of temporal double-consciousness. Adding to this complexity is the fact that Stew plays the Narrator, which is tantamount, given the audience's awareness of the musical's autobiographical elements, to playing himself. At no moment in Passing Strange is the Youth (played on Broadway by Daniel Breaker) alone on stage; the Narrator is ever-present, prodding and questioning him - part conscience, part oracle. Through rich spoken and sung dialogue between the Narrator and the Youth, the play thus constantly shuttles between the 'then' of the Youth's artistic coming of age and the 'now' of the Narrator's wary affection for his naive younger self, imbuing Passing Strange with a rich sense of history and a genuine satirical consciousness.

A second important formal innovation of Passing Strange concerns the play's presentation of music as visual spectacle. Unlike in most other Broadway musicals - in which an orchestra occupies the pit (the hollowed-out area in front of the stage) and thus is all but hidden from the audience - in Passing Strange, the five-piece band (bass, guitars, drums, keyboards) is on stage at all times. The visual presence of the musicians resonates, in turn, with AfricanAmerican musical aesthetics - in which music is realised as a call-and-response 'conversation' between players and audience - and with the play's narrative concern with the Youth's realisation of the spectacularisation of his black male performing body. It is in its canny enactment of the 'problem' of 'Negro' stage performance that Passing Strange can be understood as a 'rock musical' — not, as many of the play's reviewers have argued, because it invokes the sonic signatures of rock-and-roll. Indeed, musically speaking, Passing Strange is a glorious hybrid, drawing on a historically rich palette of sound, from minstrel-stage melodies to appropriations of American songbook/Kurt Weill-inspired idioms, to gospel, punk, Euro-pop and industrial rock. The show's brilliant lighting design, by Kevin Adams, who gained notoriety in 2007 for his lighting of the Tony Award-winning Broadway play Spring Awakening, is also noteworthy for its break from Broadway convention. In the play's most visually breathtaking moment, just before intermission, the Youth's arrival in Amsterdam is signified by the unveiling of an enormous wall of abstract shining tubes of neon lights. Their colourful, otherworldly glare symbolises new possibilities, if not an entirely new world.

Finally, and no less germane to this conversation, is the fact that all of the musicians onstage, barring Stew, appear to be white and that all of the characters in Passing Strange - from the members of the Youth's church choir to the habitués of the Amsterdam bar where he happily notices hashish on the menu - are played by actors who appear to be black or biracial. Thus, in the scenes that take place in Amsterdam and Berlin, the audience must juggle its consciousness of colour with the various 'white' roles the 'black' actors play. This strategy retroactively throws into relief the fact that in earlier scenes set in 
Los Angeles the 'black' actors are playing a variety of 'black' roles and that the Youth, in different locations and at different moments, is also playing different versions of 'himself'. The play revels in the fun of mixing it up visually, all the while making Dutch and German-accented English-performed brilliantly by the cast - a running joke.

As the preceding observations suggest, Passing Strange engages with the contradictions and challenges of 'post-civil rights' by playing loose and fast with the formal and aesthetic conventions of the Broadway musical. ${ }^{26}$ Unlike traditional Broadway fare, for example, Passing Strange does not find a happy resolution to the Youth's dilemma in marriage or romance. The play has plenty of sexual adventure - one of several crowd-pleasing songs in Act I, We Just Had Sex, is about the multiple erotic possibilities of liberated Amsterdam-yet, like the Youth himself, Passing Strange has little use for conventional romance or even Oedipal narratives. More importantly, perhaps, Passing Strange confronts its audience with its difference from the Broadway norm through its musical prelude - a blast of thumping bass, pounding drums and catchy rock-guitar hooks - and its opening moments, which draw attention in a comic fashion to the musical's self-consciousness. Initially, the Youth's mother, who is trying to persuade her son to accompany her to church, addresses him in 'Negro dialect' (as the Narrator describes it). When she realises that her tactic of 'talking black' is not working to get her son into his Sunday clothes, the Mother 'reverts' to her 'natural' (again, the Narrator's description) voice, which has a 'crisp, middle-class tone'.${ }^{27}$ In the performance I saw, the dialogue between mother and son, punctuated by wry commentary from the Narrator, earned appreciative laughter from the audience, as we recognised in the mother's linguistic code the switching that was the play's send-up of classed and raced notions of 'proper' English. ${ }^{28}$ In drawing our attention to the performativity of speech, the scene also established racial authenticity as a central question not just of this single scene, but of the play as a whole.

Here is where Passing Strange speaks most powerfully to post-civil rights contradictions, realities and possibilities. Although the Youth distances himself from American racial norms, in his overseas travels, he continues to confront issues of racial hyper-visibility and invisibility. Although he leaves the United States circa 1980, the Youth finds himself in much the same structural position as the author of Notes of a Native Son, who famously flees the nightmare of US racial apartheid to find himself the lone black person in a provincial Swiss village whose residents find perpetual novelty in his skin tone and hair texture.

26 It is relevant in regard to Broadway 'tradition' that neither Stew nor Rodewald had ever written or composed a musical before Passing Strange. For more on the process of developing and workshopping the musical, see the brief essays by Bill Bragin, Heidi Rodewald and Stew in Stew, Passing Strange, pp. ix-xix.

27 Ibid., p. 2.

28 In Spike Lee's film version, too, the moment is punctuated by audible and sustained laughter. 
On the other hand, as a subject formed in the aftermath of civil rights struggles, the Youth is far more self-assured about his status as an American citizen than Baldwin in the 1950s ever could have dared to be; indeed, because of his class privilege, the Youth, although racially defined, is also the beneficiary of a certain American nationalist presumption of geographical mobility as a mode of self-realisation, in which other countries are a 'backdrop' for his discovery of Americanness. (In this sense, the Youth's pursuit of the Real in Europe has much in common with the seemingly requisite European 'year abroad' of many white upper-class US subjects.)

The parallels between the Youth of Passing Strange and the autobiographical subject of Baldwin's early writings extend to their social and cultural formation in the black church. Baldwin, a gifted child-preacher, famously argued with the Pentecostal Church of his youth in his debut novel, Go Tell It On the Mountain (1953), and in his first play, The Amen Corner (1954), which examined the dynamics within a church community. When he returned to the United States in the late 1950s, it was to join in the work of the burgeoning civil rights movement, which drew much of its organisational and ideological strength from black Christian institutions and later, with the rise of black power, from Muslim institutions such as the Nation of Islam. The heterosexual Youth of Passing Strange also finds that he must leave the church to find himself, but, interestingly, it is a gay man in the church, Mr Franklin, a closeted queen who leads the youth choir, who plants the idea of Europe in the Youth's mind. A pivotal scene in the first act of the play juxtaposes the Narrator's (Stew's) singing of the hauntingly beautiful song Arlington Hill - a paean to the mind-expanding possibilities of recreational drugs - with dialogue between Mr Franklin and the Youth, who have been sharing a joint. As the choir director tells his protégé:

And as for this philistine fish bowl [of black bourgeois Los Angeles] we're swimmin' around in? Shoot! If you wanna deal with Le Real, I'm talking Stockholm, baby. 'Persona', yenno? I'm talking 'bout Rome and one of them 'La Dolce Vita' parties, yenno? I'm talking 'bout Godard's Paris, baby, I mean cuz we a 'Band of Outsiders' too, yenno? I mean I'm talking 'bout brother Al Calmus...'The Stranger'. Brother said, 'Algeria? See ya! Wouldn't wanna be ya!' OK? I'm talkin' little Jimmy Baldwin, baby - you gotta go to Another Country if you wanna get to Giovanni's Room! HA! That's what I'm talking 'bout! ${ }^{29}$

And even before the Youth can respond, the Narrator explicates his reaction for the audience: 'Half the time he didn't know what the fuck Mr Franklin was talking about. But that was cool.' ${ }^{30}$

29 Stew, Passing Strange, pp. 22-3.

30 Ibid., p. 23. 
In this richly allusive speech, Mr Franklin names Baldwin-in familiar terms, no less, as the 'Jimmy' by which his friends knew him-and, perhaps more importantly, foregrounds Baldwin's and his own queerness. The references to 'Another Country' and 'Giovanni's Room' have particular significance for thinking about the Youth's search for 'Le Real', especially insofar as they remind us that Baldwin's exile from the country of his birth was impelled by homophobia as well as racism. There is a poignancy here, too: as Mr Franklin, a character who embodies the legions of closeted (invisible and yet visible) black gay men in the black church, peppers his speech with references to existentialist philosophy, French New Wave cinema and the Italian film auteur Federico Fellini, we are meant to understand that these cultural productions mediate Mr Franklin's own relation to a Real that is predicated on his willingness to 'perform' heterosexuality for church elders. Like the protagonist of Go Tell It On the Mountain, Mr Franklin has a 'home' in the church, but only at the expense of sexual desire and the visibility of his queer identity. At the same time, the scene begs the issue of class difference within the Youth's church. Mr Franklin, no longer so young, has more knowledge than the Youth, but it is understood that the Europe he knows so well from books and films is beyond his means, whether those means are 'merely' monetary or means of the imagination.

\section{'Amsterdam, spring sunshine' 31}

Whereas leaving the United States entails a reprieve from the repressive Baptist Church, a baptism into new pleasures awaits the Youth on his arrival at the Headquarters Café in Amsterdam. There, he finds middle-class puritanical US social mores turned on their head, such that sexuality and the leisurely pursuit of the creative life (that is, hanging out in coffee shops) are elevated as worthwhile activities. Amsterdam is also the site of the healing of the Youth's masculinity, which has been wounded by repeated encounters with 'LA ladies in their Mercedes', ${ }^{32}$ who regard his youthful black male body as threatening. As the Youth says his goodbyes to sterile Los Angeles, he expresses special glee at the process of moving to a place where 'no-one is afraid of me' - that is, a place where women do not grab their purses as he walks by and where he is not regarded, a priori, as a criminal.

Amsterdam, however, is not a racial utopia. The Youth's initial encounter with the Dutch habitués of the Headquarters Café is shaped, as it was in Los Angeles, by others' racialised assumptions. 'So, do you play jazz?' one of the café's patron's asks on meeting him. 'Do you play duh blues?' inquires another, in Dutch-

31 I refer here to the lyric that opens the section of the musical set in Amsterdam's Headquarters Café.

32 Stew, Passing Strange, p. 47. 
accented English. (The Youth's definitive, conversation-stopping response: 'Do you live in a fucking windmill? Do you wear clog shoes?' $)^{33}$ These initial, awkward encounters, however, quickly give way to a more congenial sociality. Marianna, an attractive white Dutch waitress played by de' Adre Aziza, the same actor who portrays Edwina, the unattainable black 'teenage goddess', in the Los Angeles section of the play, asks him where he is staying in Amsterdam and, hearing that he does not have a hotel room, instinctively offers him the key to her flat. The gesture is significant because it is made unconsciously, without the hesitation of the 'LA ladies', who see the Youth through the distorting lens of what W. E. B. DuBois famously called the 'veil' of race. 'We're your new family, man!' Marianna declares, her syntax itself disrupting the peculiarly American logic of the racial binary in which a telltale 'drop' of blood determines who can be socially perceived as kin, even in the face of biological connection. ${ }^{34}$

The song Keys, the musical highlight of the Amsterdam section of Passing Strange, follows this conversation between Marianna and the Youth - as always, punctuated by occasional interjections by the Narrator. Keys begins as a duet - a form that in the Broadway canon traditionally signifies romantic possibility or, at very least, 'harmonious' feeling between the singers. It therefore anticipates the relationship between Marianna and the Youth, which blossoms during his Amsterdam sojourn. In this first section of the song, the Youth sings touchingly (at the 'vulnerable' upper end of the actor Daniel Breaker's register) of the healing effects of Marianna's 'gift' of the key. 'No more saying "uncle" to Uncle Sam,' he sings, 'I'm telling LA just where I am/Color me Amsterdam. . ${ }^{35}$ At this point, the tempo and mood of the song shift, as the Narrator takes the vocal lead, and Keys is transformed from a lyrical recitative with minimal instrumental accompaniment into a celebratory rock-gospel call-and-response, featuring vocals in Stew's deeper register and the full-on sounds of the band playing loud:

Band: Yeah, it's alright.

Narrator: Cuz she said it's alright.

Band/all: Yeah, it's alright.

Narrator: She said, 'Yeah, it [Amsterdam] might look like Sodom

From top to bottom,

A shopping mall of vice...'

But it was all right with me now.

Band/all: Yeah, it's alright.

33 Ibid., p. 44.

34 The particular 'logic' of US racial categorisation is well documented. See, for example: James F. Davis, Who is Black?: One nation's definition, Pennsylvania State University Press, University Park; Press Guterl, Matthew 2004, The Color of Race in America, 1900-1940, Harvard University Press, Cambridge, Mass. In 2009, historian Martha A. Sandweiss published Passing Strange: A gilded age tale of love and deception across the color line (Penguin, New York), about Clarence King, a prominent white guilded-age (nineteenth-century) scientist, who led a double-life as a black Pullman porter.

35 Stew, Passing Strange, p. 46. 
Narrator: Cuz she said it's alright.

Band/all: Yeah, it's alright.

(Narrator does that crazy adlib thing, which goes on for a while.) ${ }^{36}$

Here, improvised lyrical repetition ('that crazy adlib thing') joins force with high-volume ensemble singing ('Band/all') to produce a musical and narrative epiphany. After years of being relegated to 'the deep freeze' of sunny Southern California - socially chilly despite its desert warmth - the Youth's soul is thawed by the sunshine of socially enlightened Amsterdam. Marianna's key is both a 'way in' to the Youth's realisation of self-confidence and, less metaphorically, a means of access to her body. If Paris is where Baldwin's David goes to fall in love with Giovanni, Amsterdam is where the Youth of Passing Strange goes to fall in love with Marianna, and to experience the pleasures of various improvised couplings with her and other white women - couplings unthinkable (the play suggests that for the Youth they are also unprecedented) in sexually prurient and racially stratified California.

The scene of the key is thus also a key to the Youth's psychological and artistic journey, since such sexual experience infuses him with sexual and creative potency. (Here it helps that the scene is set in an age before the fear of HIV infection injected the experience of casual sex with morbid possibility.) The Youth experiences Marianna's key as the key as well to a newly masculinised mode of embodiment, in which he can experience his heterosexuality outside the distorting mirror of the white racist gaze. 'Did I say,' the Youth writes in an excited letter back home to Mr Franklin, 'that today in Amsterdam they taught me how to wear my body? ${ }^{\prime 37}$ This is romantic and even beautiful language, which clashes with the scene's celebration of access to white women's bodies as a kind of initiation, both into carnal pleasure itself and into a transgressive sexuality. Indeed, the fact that the Youth's forays signify as transgressive could be one reason why he chooses to confide his sexual adventures to the obviously closeted Mr Franklin.

To be sure, Passing Strange does not fail to bring to the audience's attention the ironies of such a statement. As the Youth writes in the very next sentence of his letter, 'Today in Amsterdam I sat before [Marianna] as she explained the history of Dutch colonialism without her shirt on. ${ }^{38}$ For the Youth, it would seem, sexual pleasure (defined here as gazing openly at Marianna's body, without fear of punishment) is inextricably interwoven with historical recollection of Amsterdam as the seat of the Dutch East India Company, the powerhouse of the Atlantic slave trade. Memory of the chained, brutalised and objectified black 
male body - in Hortense Spillers' terms, the 'de-gendered' black male bodywould seem to cast its shadow even over moments of climatic satisfaction. ${ }^{39}$ Indeed, the Youth's casual, unselfconscious mention of the Dutch colonial enterprise in his letter home draws attention to how his racial/sexual 'healing' is mediated by the histories of wounded black masculinity in the post-slavery diaspora. Although it never explicitly cites it as a source for its title, here is where Passing Strange alludes most powerfully to Othello, Shakespeare's play about sexuality across social lines of colour, rank and nationality, in which the Moor rashly imagines the infidelity of his white European wife, Desdemona. 'Tis strange, tis passing [surpassingly] strange,' Othello says, giving an account to the Venetian Senate of how his stories of life caused Desdemona to fall in love with him. Here, too, Shakespeare's text, like Stew and Rodewald's text, draws attention to the power of performance.

The play's citation of Othello, in which Desdemona dies because the very presumption of her infidelity undermines her husband's identity, strongly suggests how the narrative equation of sexuality with freedom in Passing Strange is also highly gendered. For clarification of this point, it is helpful to compare Passing Strange with two other contemporary representations of middle-class African-American youths abroad, both of them searching for some version of 'the Real'. In Andrea Lee's short story 'In France', from the book Sarah Phillips, the titular protagonist, a product of the Philadelphia black bourgeoisie, confronts the Baldwinian dilemma of 'trying to discard my portion of America' ${ }^{40}$ by going to live abroad in Paris. Like the Youth in Passing Strange, Lee's Sarah belongs to a generation of African-Americans 'educated in newly integrated schools and impatient to escape the outworn rituals of their parents' ${ }^{41}$ Sarah's confessed 'lively appetite for white boys' - a reflection, according to Valerie Smith, of her deep ambivalence about family and community-cannot, however, be sated outside the context of the physical and rhetorical violations of the black female body. ${ }^{42}$ When they make love, Sarah's white French boyfriend, Henri, calls her 'Reine d'Afrique, petite Indienne'.$^{43}$ Later, in a moment of anger brought on by class resentment (his background is working class), Henri calls Sarah 'notre Negresse pasteurizée', contracting the objectification of her sexuality with reference to her light skin tone. Whereas the Youth of Passing Strange experiences sex with Marianna as the revitalisation of masculinity, Sarah in 'In France' realises in her sexual relationship with Henri the objectification of her

39 See the much-anthologised essay Spillers, Hortense J. 1987, ‘Mama's baby, papa's maybe: an American grammar book', Diacritics: A review of contemporary criticism, vol. 17, no. 2 (Summer), pp. 65-81

40 Lee, Andrea 1984 [1993], Sarah Phillips, Northeastern University Press, Boston, Mass., p. 12.

41 Ibid., p. 4.

42 Ibid., p. xiii.

43 Ibid., p. 5. 
racialised, gendered body. She cannot write home to celebrate Paris; rather, the city makes her embarrassingly conscious of her 'hopeless presumption of trying to discard my portion of America'. ${ }^{44}$

Similarly, in Z. Z. Packer's short story 'Geese', from her collection Drinking Coffee Elsewhere, Dina, the black American female protagonist, goes to Japan, looking for the 'loveliness' she finds in Japanese teacups. ${ }^{45}$ Her reception in Tokyo is, however, decidedly different to the Youth's in Amsterdam-and the reasons for this disparity are not to be explained merely by reference to Japanese social insularity. Whereas Japanese women ignore Dina, Japanese businessmen continually proposition her: 'Verry chah-ming daaark-ku skin,' they say. ${ }^{46}$ Dina has trouble getting a job not only because she is black, but because the men expect her to sleep with them in exchange for employment. At the end of Packer's melancholy story, Dina, who shares a flat with a motley group of expatriates, resorts to selling sex as a way of earning money for food and a ticket home.

The implication of such a comparison between Passing Strange and two contemporary texts featuring black American female protagonists in Europe is that one of the Youth's dominant modes of self-discovery and self-assertion is enabled by, and inseparable from, the privileges he takes for granted as a man. These are also racialised privileges, in the sense that the Youth gains in conventionally defined 'black manhood' as he succeeds in bedding white women. The musical also works against this reading, in its rejection of a notion of black manhood contingent on desiring white women; for the narrator, that is, these are women and his nerdy reputation in the United States has got in the way of his sex life. In either case, the Youth's experience is clearly different to those of the black American women in Lee's and Packer's short works. There, sex with white men undermines their performance of conventional femininity. While this could be precisely the point, especially for Lee's protagonist, the stakes of such cross-racial sexual encounters for black women are clear.

\section{'Paradise' lost}

The Youth of Passing Strange eventually tires of Amsterdam as well, although not because of racial or sexual exploitation. Quite the contrary: he finds life in Amsterdam so 'all right' that it kills his creativity. As he tells Marianna, 'It's

\footnotetext{
44 'Notre Negresse pasteurizée' is from ibid., p. 11; the 'hopeless presumption of trying to discard my portion of America' is from p. 12.

45 Packer, Z. Z. 2005, Drinking Coffee Elsewhere, Canongate, Edinburgh, p. 190. I cite from the British edition. The first US edition was published by Riverhead Books in 2003.

46 Ibid., p. 192.
} 
hard to write songs when you're already in paradise' 47 - the 'paradise' for him consisting of access to sex, drugs and plenty of time to contemplate the role of struggling artist, which he is desperate to play. 'Real' art, he suggests, requires a certain social dis-ease that he lacks in Amsterdam, with its pleasurable but anaesthetising combination of heady sex and mind-altering drugs. Back home, in his punk-rock band, The Scaryotypes, the Youth revelled in playing the Angry Young Black Man, at war simultaneously with 'Negro mores' and 'ghetto norms', his anthem 'I'm the sole [soul] brother - up in this motherfucker' ${ }^{48} \mathrm{In}$ contrast, the Youth's comfort with the social norms of Amsterdam is discomfiting.

The Youth's next destination is West Berlin, which is on the brink of social and cultural revolution. The antithesis of faux-paradisiacal Amsterdam, where everyone is too stoned to worry about social ills, Berlin is seething with anger and twitching (the movements of the German cast of characters are literally jagged and abrupt) with nervous discontent. The Youth falls in with the Nowhaus Collective, a group of young artists committed to Destruction - to the overthrow of capitalism, the annihilation of social conventions and the obliteration of interiority itself. After a period of heady collaboration with the Nowhausians, however, the Youth is flabbergasted to find them accusing him of being a counter-revolutionary artist. Desperate for a means to prove his worthiness to the group, the Youth entices his German comrades with the one thing he knows they cannot resist: blackness steeped in the romance of the ghetto. In the face of this offering up of a romanticised 'blackness' - in a performance that is disarmingly and knowingly reminiscent of the traditions of US blackface minstrelsy - his Nowhaus comrades concede defeat. '[Your] ghetto angst,' the character Hugo tells the Youth, 'is far superior to ours.' As ever, laughter leavens this moment of seriousness, including one that raises the spectre of post-Nazi-era 'angst' about Germany's role in the Holocaust.

As this quick synopsis of its plot suggests, the German section of Passing Strange is also the height of its satire, insofar as the Youth's claims to ghetto authenticity bring the play full circle, back to the Mother's speaking in 'Negro dialect' in the opening scene. 'Do you know what it's like to hustle for dimes on the mean streets of South Central?' he asks; and of course, they have no clue. Passing Strange conveys a contagious pleasure in the send-up of authenticity here: in the Youth's knowingly inauthentic performance of 'realness', in the Germans' inability to resist romanticised images of racialised oppression and in the fact that its own satire of 'passing for black' should take a detour through such absurdist terrain, with self-exoticisation its ugly and yet strategic destination.

47 Stew, Passing Strange, p. 52.

48 Ibid., p. 27. 
The differences between Amsterdam and Berlin are signified musically as well. Whereas the songs in the Amsterdam section of the play are emotionally tender, lyrical and played at a comfortable volume, the sounds of Berlin are loud. The exception is The Black One, the Berlin section's most hilarious number, which sonically sends up the quintessential Broadway musical ensemble piece. In this relentlessly upbeat song, the Youth and his German artist-anarchist friends celebrate the 'realness' of the spectacle of blackness performed for white consumption. The funny-sad punchline of the song is delivered by the dour Sudabey, who announces her envy of the Youth in imperfect English. In the next life, she says, 'I want to be re-incarcerated [sic] as a black man!!!'49

The over-the-top racial burlesque of the Berlin section of the play, particularly in the song The Black One, links Passing Strange with other post-civil rights cultural productions that use satire, rather than social realism, as a formal means by which to make visible the contradictions of twenty-first-century racial discourse..$^{50}$ In their eager embrace of the Youth as an authentic Voice of the Oppressed, the members of the Nowhaus Collective exemplify this contradiction: although they reject notions of interiority ('What's inside is just a lie,' they tell a startled Youth), they are almost magically seduced by his claims of AfricanAmerican 'realness'. While they profess to care deeply about social oppression, they are comically detached from social activism - that is, less interested in 'real' black people than in narratives of blackness they can use to enhance their radical credentials. Likewise, as the Youth discovers at Christmas, while the Nowhausians shun the bourgeois family, they look forward to returning for the holiday to the hamlets of their birth, where they can revert to simple childhood pleasures.

The laughter produced by Stew's satire of German radical chic is, to be sure, wickedly double-edged, a simultaneous send-up of white colour blindnesswhich is in fact exquisitely aware of racial categories and their attendant social meanings - and of black strategies of appropriating this discourse of colour blindness. The Youth's willingness to play the role of the 'Black One' is tragicomic, a sign of his entrapment within racial discourse as well as his sophisticated understanding of how 'race' can be used to entrap others. Paul Beatty's 1996 novel, The White Boy Shuffle, which tells the story of a middle-class black boy who takes up the various guises of authenticity thrust on him ('the cool black one', the spokesman for black experience, the prophet of blackness), similarly sends up US notions of colour blindness and multiculturalism with comic relish. While Beatty's novel embraces nihilism in its absurdist ending, in which the protagonist convinces African-Americans to commit collective

49 Ibid., p. 82. The pun earns the actor a big laugh.

50 In 'The new black aesthetic', Ellis argues that satire and parody are important aspects of the 'postliberated aesthetic' (p. 236) of contemporary black artists. 
suicide, Passing Strange, however, dares to examine the 'tears' behind the superficial merriment of the neo-minstrel mask. Wearing the mask 'that grins and lies', as Paul Laurence Dunbar writes in his 1896 poem, can serve as a means of African-American survival, but it works at the expense of AfricanAmerican collective self-expression. ${ }^{51}$ Whereas Beatty's protagonist becomes a bard of black collective self-annihilation, the Youth in Passing Strange instead probes the possibility of the meaning of the 'Real' beyond racial impersonation.

The Youth's quest and the narrative of Passing Strange come to a head in Work the Wound, the song that bridges the Berlin section of the play and the ending, in which the Youth returns home for his mother's funeral. Here the figures of the Youth and the Narrator are joined, as the Narrator sings (in the first person) about the masking potential of art and the discovery that songs of personal pain can also be sources of entertainment for others. Like satire, performance is double-edged. 'And I'm blessed to entertain,/The crowd laughs and swoons,' the Narrator sings in the first version of the chorus. 'See, I'm cursed to entertain,/ The crowd laughs too soon,' he sings in the second version. Either way, the song implicates the audience in the dualism of performance as blessing and curse. What does it mean, the song asks us, that we are capable of being diverted by spectacles of suffering; that the development of American musical and performing arts has depended on white Americans' fetishisation of the black performing body; that black subjects have long been imagined as possessing an inherent (racialised) gift of jollity and entertainment ${ }^{52}$

Passing Strange ends with the Youth's/the Narrator's return home to Los Angeles, but, significantly, it celebrates maternal love and homecoming without reifying either as the salve that can heal the wounds described in Work the Wound. Indeed, the reunion of mother and son is infinitely deferred by her death, although the play allows the audience the pleasure of imagining them together in real time by presenting both actors on stage. Such refusal to conflate 'motherland' with mother love constitutes yet another means by which Passing Strange swerves away from conventional racial narratives. For even as he sings about idealised mother love as a kind of 'Real', so the Narrator affirms what the play has known all along: that the Real is 'a personal sunset.../You drive off into alone'. ${ }^{53}$ The line as such is not ironic - or didn't seem so to me when I heard it performed - even as it invokes multiple images of 'American' road narratives, from John Wayne and Jack Kerouac to Thelma and Louise. The impossibility of ever returning to the innocence of youth/the Youth is the paradoxical condition of homecoming.

51 Laurence Dunbar, Paul 1993, 'We wear the mask', in Joanne M. Braxton (ed.), The Collected Poetry of Paul Laurence Dunbar, University of Virginia Press, Charlottesville.

52 These issues are explored at greater length in Hartman, Saidiya V. 1997, Scenes of Subjection: Terror, slavery, and self-making in nineteenth-century America, Oxford University Press, New York.

53 Stew, Passing Strange, p. 101. 
All the same, in the end, Passing Strange refuses nostalgic allegiance to a (racialised) past that might be embodied in mother or motherland. It also represents black male self-definition as a project that can take place outside what Mark Anthony Neal, in his discussion of the post-civil rights, terms the 'killthe-father' narratives of black expressive culture. (As an example, one might think of the way Baldwin staged his own literary 'birth' in a scathing assessment of the limitations of the work of his mentor, Richard Wright.) $)^{54}$ Perhaps most importantly for this discussion, Passing Strange affirms the 'strangeness' of identity itself. 'Black is... [and] black ain't,' as the film-maker Marlon Riggs put it. Or, as the Mother sings to her son, in a life-affirming intergenerational lullaby from beyond the grave:

Don't be sad about your chosen path,

And where it's taken you thus far

Cuz this is what you did,

And that is who you are.

And it's alright. ${ }^{55}$

Like the musical's earlier reference to 'a personal sunset.../You drive off into alone', this closing lullaby, while delivered tenderly and without apparent irony, must be read through the complexities of Passing Strange. Rather than an essentialist assertion, this is an ontological statement rendered ironic through the 'strange' theatricality of identity in post-civil rights America.

54 I am referring to Baldwin's 1949 essay 'Everybody's protest novel', which accuses American literary works from Harriet Beecher Stowe's Uncle Tom's Cabin to Wright's Native Son of being incapable of representing African-American humanity. The essay was republished in Notes of a Native Son, 1964, Bantam Books, New York.

55 Stew, Passing Strange, p. 100. 